\title{
Degradation of copepod fecal pellets: key role of protozooplankton
}

\author{
Louise K. Poulsen ${ }^{1,2, *}$, Morten H. Iversen ${ }^{3}$ \\ ${ }^{1}$ Danish Institute for Fisheries Research, Department of Marine Ecology and Aquaculture, Kavalergården 6 , \\ 2920 Charlottenlund, Denmark \\ ${ }^{2}$ Marine Biological Laboratory, University of Copenhagen, Strandpromenaden 5, 3000 Helsingør, Denmark \\ ${ }^{3}$ Alfred-Wegener Institute for Polar and Marine Research, Am Handelshafen 12, 27570 Bremerhaven, Germany
}

ABSTRACT: Copepod fecal pellets are often degraded at high rates within the upper part of the water column. However, the identity of the degraders and the processes governing the degradation remain unresolved. To identify the pellet degraders we collected water from Øresund (Denmark) approximately every second month from July 2004 to July 2005 . These water samples were divided into 5 fractions $(<0.2,<2,<20,<100$, $<200 \mu \mathrm{m}$ ) and total (unfractionated). We determined fecal pellet degradation rate and species composition of the plankton from triplicate incubations of each fraction and a known, added amount of fecal pellets. The total degradation rate of pellets by the natural plankton community of Øresund followed the phytoplankton biomass, with maximum degradation rate during the spring bloom $\left(2.5 \pm 0.49 \mathrm{~d}^{-1}\right)$ and minimum $(0.52 \pm$ $0.14 \mathrm{~d}^{-1}$ ) during late winter. Total pellet removal rate ranged from $22 \% \mathrm{~d}^{-1}$ (July 2005) to $87 \% \mathrm{~d}^{-1}$ (May). Protozooplankton (dinoflagellates and ciliates) in the size range of 20 to $100 \mu \mathrm{m}$ were the key degraders of the fecal pellets, contributing from 15 to $53 \%$ of the total degradation rate. Free-living in situ bacteria did not affect pellet degradation rate significantly; however, culture-originating bacteria introduced in association with the pellets contributed up to $59 \%$ of the total degradation rate. An effect of late-stage copepod nauplii $(>200 \mu \mathrm{m})$ was indicated, but this was not a dominating degradation process. Mesozooplankton did not contribute significantly to the degradation. However, grazing of mesozooplankton on the pellet degraders impacts pellet degradation rate indirectly. In conclusion, protozooplankton seems to include the key organisms for the recycling of copepod fecal pellets in the water column, both through the microbial loop and, especially, by functioning as an effective 'protozoan filter' for fecal pellets.

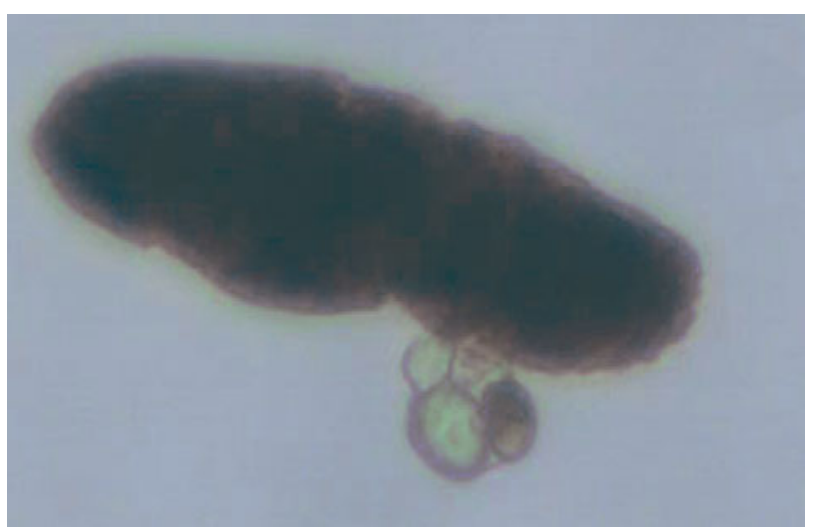

Protozooplankton organisms (dinoflagellates and ciliates) are key degraders of copepod fecal pellets: Gyrodinium dominans draws pellet material into a food vacuole through the open transversal groove.

Photo: L. K. Poulsen

KEY WORDS: Bacteria $\cdot$ Copepod $\cdot$ Degradation rate $\cdot$ Dinoflagellates · Fractionated plankton community · Protozoan filter $\cdot$ Nauplii

Resale or republication not permitted without written consent of the publisher

\section{INTRODUCTION}

The processes governing the degradation of copepod fecal pellets in the sea are poorly known. Fecal pellets produced in the upper ocean are often degraded in the water column at high rates (Turner 2002, Poulsen \& Kiørboe 2005). Bacteria degrade pellets, and copepods can degrade pellets through coprorhexy 
(fragmentation of pellets), coprophagy (ingestion of pellets) and coprochaly (loosening of pellets) (Lampitt et al. 1990, Noji et al. 1991). Especially copepods have been proposed as the main degraders of copepod fecal pellets, since several copepods have been shown to degrade fecal pellets in the laboratory (Paffenhöfer \& Strickland 1970, Paffenhöfer \& Knowles 1979, Paffenhöfer \& Van Sant 1985, Ayukai \& Nishizawa 1986, Lampitt et al. 1990, Noji et al. 1991, González \& Smetacek 1994, González et al. 1994). However, evidence for the major role of copepods in the field is lacking. To our knowledge, copepod fecal pellet degradation has only been investigated in one field study by Poulsen \& Kiørboe (2006), who found that copepods were not important degraders of fecal pellets and suggested that plankton organisms $<200 \mu \mathrm{m}$ were the main degraders. Furthermore, recent studies combining grazing experiments and visual observation of feeding behavior have shown that some copepods do not view fecal pellets as attractive food particles, and actual ingestion by suspension-feeding calanoids appears to consist of small fragments. These fragments are mainly ingested unintentionally along with food particles contained within the feeding current (Poulsen \& Kiørboe 2005, Iversen \& Poulsen 2007).

Evidence for fecal pellet degradation by planktonic organisms other than adult copepods does exist but is very scarce. Nauplii of the hapacticoid copepod Amonardia normanni (Koski et al. 2005) and Calanus helgolandicus (Green et al. 1992) consume fecal pellets. Kiørboe (2003) found high clearance rates of the heterotrophic dinoflagellate Noctiluca scintillans on fecal pellets in an upwelling plume off the coast of Brazil ( $\left.600 \mathrm{ml} \mathrm{cell}^{-1} \mathrm{~d}^{-1}\right)$. Ciliates and heterotrophic flagellates may colonize fecal pellets and have been observed to increase pellet degradation (Hansen et al. 1996).

This study investigates the degradation of copepod fecal pellets by the plankton community of Øresund (Denmark). The degradation rate of fecal pellets by the unfractionated plankton community, as well as of the 5 size classes (ultra-, pico-, nano-, micro- and mesoplankton), was investigated through incubations of fecal pellets with the total plankton community and the 5 size fractions. The species composition of the plankton community was quantified to evaluate the degradation of specific plankton groups and species in detail. Our main goal was to pinpoint the plankton organisms responsible for pellet degradation and to quantify the impact of these organisms throughout the year. Thus, only 1 type of fecal pellets was used in the degradation experiments, eliminating the influence of other possible governing factors for pellet degradation rate, such as the food source of the pellets, pellet size, pellet age, etc.

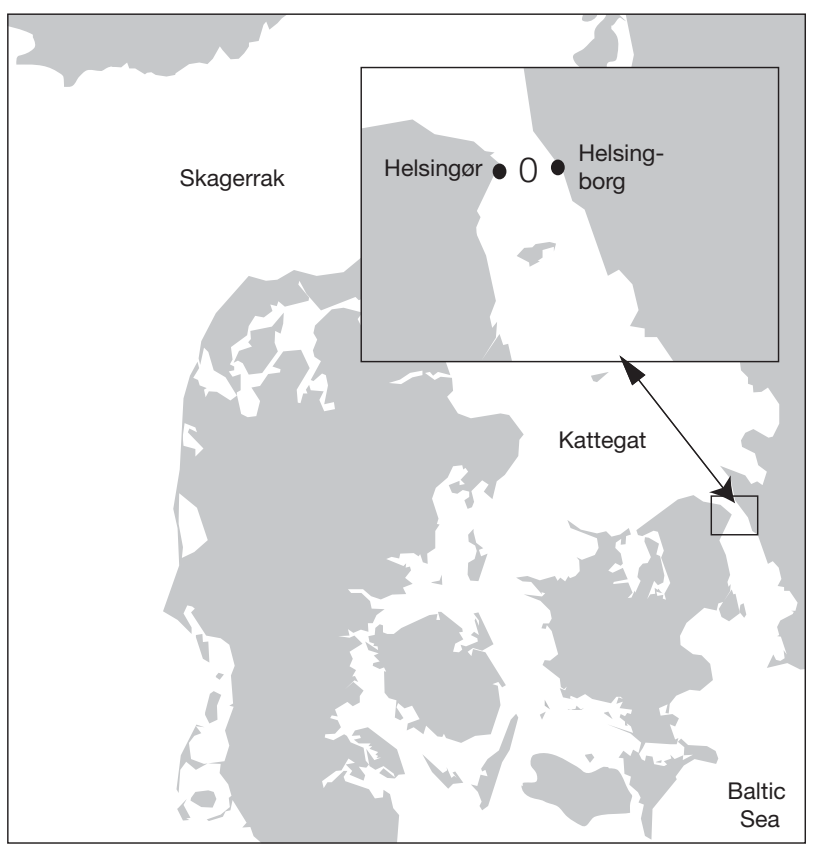

Fig. 1. Sampling area. Sampling was conducted approximately every second month during a year (2004/2005) in the strait of Øresund between Denmark and Sweden. Sampling of the plankton community was conducted at the depth of the fluorescence maximum

\section{MATERIALS AND METHODS}

Sampling and location. Sampling for plankton was conducted approximately every second month throughout a year in the narrow strait of Øresund, located between Denmark and Sweden (Fig. 1, Table 1). Øresund is characterized by a strong halocline throughout the year with low-saline $(\sim 10 \%)$ surface water from the Baltic Sea and saline $(\sim 30 \%)$ bottom water from the Kattegat (Lintrup \& Jakobsen 1999). Strong wind events may break up the halocline periodically. Water samples for experimentation were collected at the depth of the fluorescence maximum in the lower part

Table 1. Sampling data. Sampling depth was the depth of the fluorescence maximum in the lower part of the halocline

\begin{tabular}{|lcccc|}
\hline $\begin{array}{l}\text { Sampling } \\
\text { date }\end{array}$ & $\begin{array}{c}\text { Sampling } \\
\text { depth } \\
(\mathrm{m})\end{array}$ & $\begin{array}{c}\text { Total } \\
\text { depth } \\
(\mathrm{m})\end{array}$ & $\begin{array}{c}\text { Temperature } \\
\left({ }^{\circ} \mathrm{C}\right)\end{array}$ & $\begin{array}{c}\text { Salinity } \\
(\% \circ)\end{array}$ \\
\hline 6 Jul 2004 & 9 & 20 & 16 & 28 \\
18 Aug 2004 & 12 & 25 & 16 & 28 \\
8 Sep 2004 & 12 & 25 & 14 & 28 \\
2 Nov 2004 & 9 & 20 & 12 & 28 \\
24 Feb 2005 & 19 & 35 & 5 & 22 \\
16 Mar 2005 & 8 & 20 & 4 & 26 \\
17 May 2005 & 15 & 25 & 7 & 18 \\
28 Jul 2005 & 16 & 39 & 14 & 33 \\
\hline
\end{tabular}


of the halocline ( 8 to $19 \mathrm{~m}$ ) (Table 1 ) by use of a water pump. The fluorescence maximum was determined through vertical profiles of temperature, salinity and fluorescence using a SeaBird SBE11 CTD equipped with an in situ fluorometer. The water was immediately transported to the laboratory in $30 \mathrm{l}$ plastic containers. In the laboratory the containers were kept at in situ temperature and gently aerated.

Cultures and pellet production. Rhodomonas salina (Wislouch) Hill \& Wetherbee (a cryptophyte) was maintained in exponential growth in $f / 2$ medium (Guillard 1975). The cultures were kept in a constant light:dark cycle $(12: 12 \mathrm{~h})$ in filtered seawater $(\sim 33 \%)$ at $18^{\circ} \mathrm{C}$. Acartia tonsa was kept in culture at $18^{\circ} \mathrm{C}$ and reared on $R$. salina (Støttrup et al. 1986). The fecal pellets added in the degradation experiment of each sampling month were produced by 1 cohort of $A$. tonsa females feeding on $R$. salina at saturating food concentrations (>713 $\mu \mathrm{gC} \mathrm{l}^{-1}$; Kiørboe et al. 1985). Screen insets $(180 \mu \mathrm{m})$ in the bottom of the pellet production containers minimized coprophagous and coprorhexious grazing of the pellets by $A$. tonsa. The copepods were allowed to feed for $<18 \mathrm{~h}$ before the pellets were separated from phytoplankton and copepods by filtration through a double filter with an upper $180 \mu \mathrm{m}$ screen (removes copepods) and a lower $30 \mu \mathrm{m}$ screen (collects pellets but not $R$. salina). The pellets were then gently washed and suspended in a single bottle with filtered seawater $(<0.2 \mu \mathrm{m}$ micropore filter), which was used as the stock solution of pellets. The pellet concentration in the stock solution was calculated from pellet counts (pellet fragments [end parts only] were counted as a one-half pellet). The average volume (cylindrical shape) of the pellets was calculated from measurements of length and width of at least 30 fecal pellets (Table 2). Subsamples were immediately transferred to the incubation bottles containing the different plankton fractions (within $1 \mathrm{~h}$ of production) corresponding to a final fecal pellet concentration of $\sim 0.5$ pellets $\mathrm{ml}^{-1}$.

Table 2. Experimental data and fecal pellet characteristics at incubation start. Pellet volume was calculated from measurements of pellet length and width. Pellet length and volume $( \pm \mathrm{SD})$ given as means

\begin{tabular}{|lcrrc|}
\hline $\begin{array}{l}\text { Sampling } \\
\text { date }\end{array}$ & $\begin{array}{c}\text { Incubation } \\
\text { time }(\mathrm{h})\end{array}$ & $\begin{array}{c}\text { Length } \\
(\mu \mathrm{m})\end{array}$ & $\begin{array}{c}\text { Volume } \\
\left(10^{4} \mu \mathrm{m}^{3}\right)\end{array}$ & $\begin{array}{c}\text { Fragmenta- } \\
\text { tion }(\%)\end{array}$ \\
\hline 6 Jul 2004(a) & 48 & $66( \pm 42)$ & $3.4( \pm 5.4)$ & 44 \\
6 Jul 2004(b) & 48 & $80( \pm 30)$ & $6.0( \pm 4.8)$ & 34 \\
18 Aug 2004 & 48 & - & - & - \\
8 Sep 2004 & 48 & $93( \pm 23)$ & $5.2( \pm 2.0)$ & 26 \\
2 Nov 2004 & 24 & $91( \pm 24)$ & $7.4( \pm 3.9)$ & 34 \\
24 Feb 2005 & 24 & $79( \pm 17)$ & $5.5( \pm 2.5)$ & 45 \\
16 Mar 2005 & 24 & $95( \pm 37)$ & $9.1( \pm 5.6)$ & 39 \\
17 May 2005 & 24 & $111( \pm 34)$ & $12.4( \pm 6.2)$ & 19 \\
28 Jul 2005 & 24 & $85( \pm 16)$ & $8.2( \pm 4.2)$ & 30 \\
\hline
\end{tabular}

Degradation experiments. Water from the fluorescence maximum of Øresund was fractionated into 5 fractions $(<0.2,<2,<20,<100,<200 \mu \mathrm{m})$ and total (unfractionated) to evaluate the pellet degradation rate attributable to the different plankton size groups at in situ concentrations $(0.2$ to $2 \mu \mathrm{m}=$ bacteria, 2 to $20 \mu \mathrm{m}$ = nanoplankton, 20 to $200 \mu \mathrm{m}=$ microplankton and $>200 \mu \mathrm{m}=$ mesozooplankton). The water was fractionated into the size classes $<20,<100$ and $<200 \mu \mathrm{m}$ by inverse filtration through 20, 100 and $200 \mu \mathrm{m}$ filters and into the $<0.2$ and $<2 \mu \mathrm{m}$ size fractions by use of, respectively, a $0.2 \mu \mathrm{m}$ and $2 \mu \mathrm{m}$ micropore filter mounted on a suction system. Water from each fraction and the unfractionated (total) sample was incubated in triplicate for $48 \mathrm{~h}$ (July and September 2004) or $24 \mathrm{~h}$ (other months) (Table 2) after addition of 300 fecal pellets from the pellet solution per $615 \mathrm{ml}$ blue cap incubation bottle $\left(=0.5\right.$ pellets $\left.\mathrm{ml}^{-1}\right)$. Control bottles (3 replicates), without addition of pellets, were made for the size fractions containing in situ copepod fecal pellets and copepods: $<20,<100,<200 \mu \mathrm{m}$ and total. These controls were used to correct for in situ pellets and pellets produced by copepods present in the water samples during incubation. Bottles were incubated on a plankton wheel (1 rpm), kept at in situ temperatures (i.e. temperature at sampling depth; Table 1), and on a $12 \mathrm{~h}$ light:12 h dark cycle. After incubation, fecal pellets and zooplankton were collected on a $15 \mu \mathrm{m}$ filter, stored in $50 \mathrm{ml}$ plastic containers and preserved by acid Lugol's solution (1\% final concentration) for later counting.

The degradation experiment carried out in August 2004 was contaminated by the mainly benthic ciliate Euplotes sp. (from the Rhodomonas salina culture), and therefore discarded; in this experiment, all fecal pellets were degraded within $48 \mathrm{~h}$. Two degradation experiments (Expts a and b) were run in parallel in July 2004, with water from the same sample and same size fractions. The parallel experiments were conducted to investigate how the initial degree of pellet fragmentation influenced the pellet degradation rate. The pellets were produced by the same cohort of Acartia tonsa females as described above. However, different pellet fragmentation percents were obtained by filtration, such that fragmentation was $44 \%$ in Expt a and $34 \%$ in Expt b (Table 2). Pellets for Expt a were filtered through a double filter with an upper $180 \mu \mathrm{m}$ screen (removes copepods) and a lower $15 \mu \mathrm{m}$ screen (collects pellets). Pellets for Expt b were filtered through a double filter with an upper $180 \mu \mathrm{m}$ screen and a lower $30 \mu \mathrm{m}$ screen. The fragmentation percent $(F)$ of the fecal pellets was calculated as:

$$
F=\frac{(\text { fragments } / 2)}{\text { Intact }+(\text { fragments } / 2)} \times 100 \%
$$


where fragments are a one-half pellet (end parts only) and intact is whole pellets.

The fecal pellet degradation rate was calculated from the loss of fecal pellet material described by:

$$
N_{t}=N_{0} \mathrm{e}^{-r t}
$$

where $N$ is the total number of fecal pellets in the incubation bottle at incubation start $\left(N_{0}\right)$ and at the end of incubation $\left(N_{t}\right), t$ is incubation time (days) and $r$ is the degradation rate $\left(\mathrm{d}^{-1}\right)$. The degradation rate estimated in this study is a cumulative degradation rate in the sense that organisms present in the fraction $<0.2 \mu \mathrm{m}$ are also present in all other fractions, the organisms present in the fraction $<2 \mu \mathrm{m}$ are present in all other fractions except $<0.2 \mu \mathrm{m}$ and so forth. The degradation rate of fecal pellets in the unfractionated samples is called the total degradation rate.

Control experiments. A control experiment was conducted to ensure that the handling procedure did not affect the pellet degradation rates. Two subsamples of $5 \mathrm{ml}$ were taken from a pellet stock solution. One of the samples was placed directly in a Petri dish. The other sample was added to a Bluecap bottle filled with filtered seawater $(<0.2 \mu \mathrm{m})$, collected on a $15 \mu \mathrm{m}$ filter and flushed into a Petri dish, following the same procedure as in the degradation experiments of the present study. The 2 subsamples were fixed with acid Lugol's solution simultaneously and counted. The procedure was repeated 6 times with new subsamples from the pellet solution, and a $t$-test (SigmaStat 3.1) was conducted to test for significant differences between the 2 treatments. No differences between the recovered pellets in the 2 treatments were found ( $p>0.05)$, i.e. the handling procedure did not affect the pellet degradation rate.

Counting. The total number of pellets in all size fractions and in the controls of the size fractions of $<20$, $<100,<200 \mu \mathrm{m}$ and total were counted after incubation (3 replicates in all size fractions). The concentration of Acartia tonsa pellets after incubation was calculated by subtracting the average number of pellets in the control bottles ( 3 replicates) from the total number of pellets left in each incubation bottle (3 replicates) of the corresponding size fraction. After incubation all 6 size fractions (3 replicates in each fraction) were fixated with acid Lugol's solution, and the zooplankton species composition was assessed by use of a stereo microscope. Thus, the zooplankton in each fraction represents the in situ concentration of the zooplankton. All animals were identified to species or genus level. Samples for enumeration and identification of phytoplankton and protozooplankton were taken in each of the 6 size fractions prior to incubation and fixed in acid Lugol's solution (1\% final concentration). Counting was conducted in Utermöhl settling chambers (settling time $>24$ h) (Utermöhl 1958). Only cells $>10 \mu \mathrm{m}$ were counted, since smaller cells are not satisfactorily determined with the Utermöhl method. At least 400 cells were counted per sample. Biovolumes of protists were estimated from linear dimensions using appropriate geometric shapes, and were converted to biomass using 2 linear regression equations of carbon:volume relationships, 1 for diatoms (Mullin et al. 1966):

$$
\log C=0.76 \log V-0.29
$$

and 1 for flagellates (autotrophic and heterotrophic) (Menden-Deuer \& Lessard 2000):

$$
\log C=0.94 \log V-0.6
$$

where $C$ is cell carbon mass in pg and $V$ is cell volume in $\mu \mathrm{m}^{3}$.

Identification of ciliates to species, group, or morphotype was based on Montagnes \& Lynn (1991) and Hansen \& Nielsen (1999). Dinoflagellates were identified according to Tomas (1997) and Thomsen (1992). No correction for cell shrinkage was applied. Protozooplankton was divided into the size classes $<20$ and $>20 \mu \mathrm{m}$ according to the shortest dimension. Separation of autotrophic and heterotrophic dinoflagellates was not complete, as this is only possible with $100 \%$ precision using epifluorescence microscopy.

Chlorophyll a. Samples (1 to 3 l) for chl a measurements of the unfractionated water were filtered onto GF/F filters, extracted in $96 \%$ ethanol and measured on a Perkin Elmer spectrophotometer. No chl a measurements were conducted in July 2004 and September 2004

Statistical analysis. The difference between the degradation rates of fecal pellets (dependent variable) in the 5 size fractions and the unfractionated water sample of each month (factor) was tested with 1-way ANOVA. The Tukey post hoc test was used for pairwise comparisons (SigmaStat 3.1).

The importance of the initial degree of pellet fragmentation for the pellet degradation rate of the parallel experiments in July 2004 (Expts a and b; Table 2) was tested with a $t$-test comparing the average degradation rates (see Fig. 5A, B) of each of the 5 size fractions and total between Expts a and b (SigmaStat 3.1).

The correlation between temperature and average bacterial degradation rate $(<0.2$ and $<2 \mu$ m fractions) was determined through a Pearson product moment correlation (SigmaStat 3.1).

Stepwise linear regression was used to find the best model describing the relationship between pellet degradation rate (dependent variable) and the abundance of different protozooplankton and zooplankton organisms (independent variables) in the size ranges of 20 to $100 \mu \mathrm{m}$ (microzooplankton) and $\geq 200 \mu \mathrm{m}$ (mesozooplankton). The degradation rate in the 2 size ranges 
was obtained by subtraction $\left(r_{20-100 \mu \mathrm{m}}=r_{<100 \mu \mathrm{m}}-r_{<20 \mu \mathrm{m}}\right.$ and $\left.r_{\geq 200 \mu \mathrm{m}}=r_{\text {total }}-r_{<200 \mu \mathrm{m}}\right)$; the same was done for animal abundances. September was excluded from the analysis due to contamination of the $<0.2$ and $<2 \mu \mathrm{m}$ fractions with protozooplankton, making it impossible to separate the bacterial contribution from that of the other fractions. Linear regression was done for each independent variable, and significant variables $(\mathrm{p}<$ 0.05) were investigated in all possible combinations through stepwise linear regression (SigmaStat 3.1) to search for the best model, describing the dependence of the degradation rate on the relevant independent variables in the 2 size ranges. Residuals were analyzed to confirm that model assumptions were satisfied, and the models were tested for autocorrelation and multicollinearity (correlation between independent variables).

\section{RESULTS}

\section{Hydrography and plankton}

A strong halocline was present at 10 to $20 \mathrm{~m}$ depth, except in February, when strong winds broke it up. The fluorescence maximum was generally located in the lower part of the halocline (8 to $19 \mathrm{~m}$; Table 1). Phytoplankton blooms were observed, 1 in March, May and July 2005 (267 to $512 \mu \mathrm{g} \mathrm{Cl}^{-1}, 3$ to $7 \mu \mathrm{g} \mathrm{chl} \mathrm{a}^{-1}$ ) and 1 in the autumn (September, $167 \mu \mathrm{g} \mathrm{C}^{-1}$ ) (Figs. 2 \& 3A). During the rest of the sampling months concentrations of 2 to $39 \mu \mathrm{C} \mathrm{l}^{-1}$ and 0.3 to $1.7 \mu \mathrm{g} \mathrm{chl} \mathrm{a} \mathrm{l}^{-1}$ prevailed in the subsurface maximum.

The heterotrophic biomass was dominated by protozooplankton (dinoflagellates and ciliates) in all months and followed the seasonal variation in phytoplankton biomass (Figs. 2 \& 3B). Dinoflagellates dominated the protozooplankton in all months (Fig. 3B). The large protozooplankton groups $(>20 \mu \mathrm{m})$ present in the $<100 \mu \mathrm{m}$ fraction included the autotrophic/ mixotrophic dinoflagellates Ceratium spp. and Dinophysis spp., heterotrophic dinoflagellates $>20 \mu \mathrm{m}$, Gyrodinium spirale (Bergh) Kofoid \& Swezy, Protoperidinium spp. and ciliates $>20 \mu \mathrm{m}$.

The zooplankton community of Øresund consisted of relatively few species, which were dominated by small copepods (Fig. 4). Copepod nauplii were found in the plankton throughout the year, with a maximum abundance in July $2005\left(65 \pm 16\right.$ ind. $\left.\mathrm{l}^{-1}\right)$ and minimum in February $\left(4 \pm 3\right.$ ind. $\left.\mathrm{l}^{-1}\right)$. Maximum copepod abundances of 22 to 60 ind. $\mathrm{l}^{-1}$ were found in July and September (Fig. 4). Oithona similis was present in all months except March and dominated the zooplankton community except in spring, when Acartia spp. dominated. Evidence of high grazing pressure exerted by the mesozooplankton during their maximum abundance was observed in the degradation experiment of July 2005. This was due to the general disruption and senescence of the phytoplankton, large amounts of dead organic matter originating from disrupted fecal pellets, and to a low abundance of large (>20 $\mu \mathrm{m})$ protozooplankton (Fig. 3B).
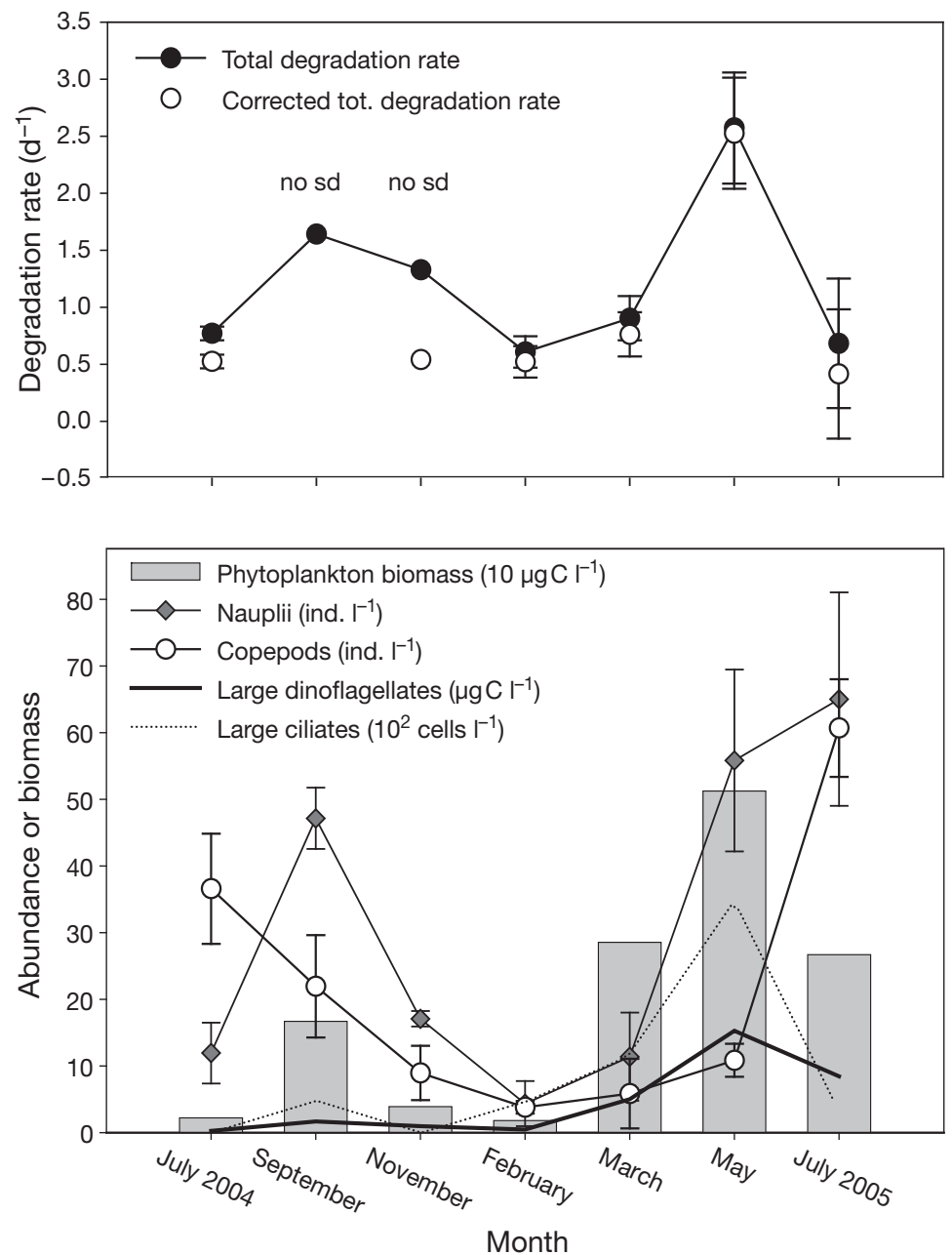

Fig. 2. Total degradation rate and plankton abundances in the unfractionated water samples (total). The total degradation rate $\left(\mathrm{d}^{-1}\right)$ and the corrected total degradation rate $\left(\mathrm{d}^{-1}\right)$ are presented in the upper panel. The corrected total degradation rate represents the total degradation rate of the natural plankton community, from which the contribution of the culture-originating bacteria $(<0.2 \mu \mathrm{m}$ fraction) has been subtracted (excluding September). Phytoplankton biomass $\left(\times 10 \mu \mathrm{g} \mathrm{Cl}^{-1}\right)$; biomass of large $(>20 \mu \mathrm{m})$, heterotrophic dinoflagellates $\left(\mu \mathrm{C} \mathrm{l}^{-1}\right)$; abundance of large $(>20 \mu \mathrm{m})$ ciliates $\left(\times 10^{2}\right.$ cells $\left.\mathrm{l}^{-1}\right)$; nauplii abundance (ind. $\left.\mathrm{l}^{-1}\right)$ and copepod abundance (ind. $\mathrm{l}^{-1}$ ) are presented in the lower panel. Total degradation rate, nauplii and copepod abundances are represented as the average $( \pm$ SD) for July 2004 Expts a and b 

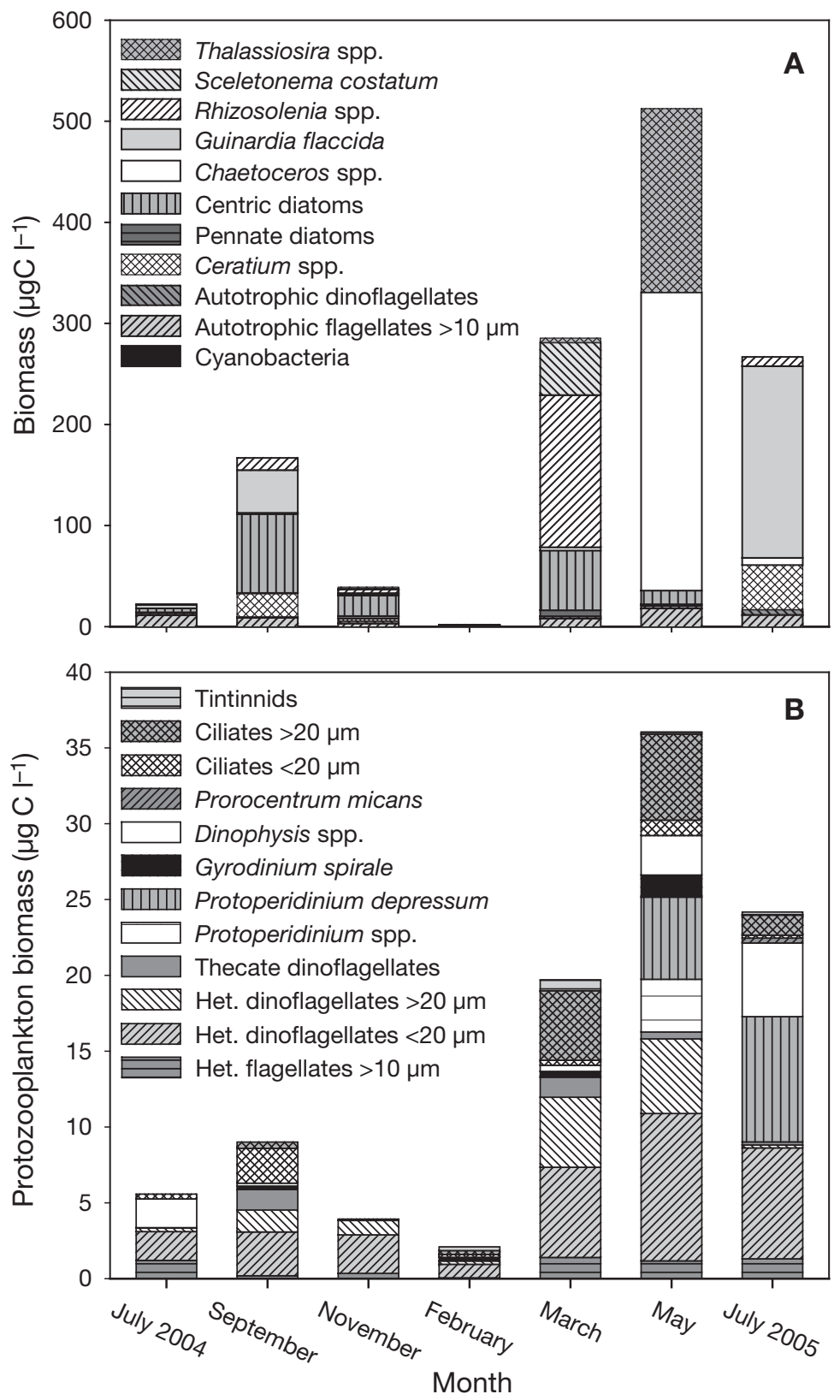

Fig. 3. Plankton biomass and species composition. (A) phytoplankton and (B) protozooplankton in the unfractionated water samples of each month. The phytoplankton community was dominated by Chaetoceros spp. and autotrophic flagellates $>10 \mu \mathrm{m}$ in February. Only autotrophic flagellates $>10 \mu \mathrm{m}$ could be satisfactorily determined with the Utermöhl method. Cyanobacteria here are colonial forms. Dinoflagellates and ciliates were determined from shortest dimension

\section{Degradation of fecal pellets}

The results of the pellet degradation experiments in the present study revealed that bacteria associated with the pellets and protozooplankton in the size range of 20 to $100 \mu \mathrm{m}$ were the major plankton groups responsible for pellet degradation.
The degradation rate was not significantly different between the $<0.2,<2$ and the $<20 \mu \mathrm{m}$ size fractions, except in May (Fig. 5). Furthermore, the degradation rate was significantly different from zero in the $0.2 \mu \mathrm{m}$ fraction (except in May). All in situ bacteria were removed from the seawater via filtration in this fraction; we therefore suggest that bacteria associated with the pellets (cultureoriginating) were responsible for the degradation rate in these size ranges. The degradation rate provided by the naturally occurring bacteria was small, as seen from the insignificant contribution of the $<2 \mu \mathrm{m}$ size fraction compared to that of the $<0.2 \mu \mathrm{m}$ fraction. The average degradation contributed by the naturally occurring bacteria (the size range of 0.2 to $2 \mu \mathrm{m}$ ) ranged from 15 to $4 \%$ of the total degradation rate in all months (Fig. 6), except in July 2005, when the contribution was $29 \%$, corresponding to a degradation rate of $0.2 \mathrm{~d}^{-1}$ (Fig. 5H). The degradation rate of the culture-originating bacteria ranged from 0.05 to $0.79 \mathrm{~d}^{-1}(<0.2 \mu \mathrm{m}$ fraction) contributing from 2 to $59 \%$ of the total degradation rate. September was not included, since the $<0.2$ and $<2 \mu \mathrm{m}$ fractions were contaminated by protozooplankton. There was no correlation ( $p>0.05$ ) between temperature and average degradation rate of pellets by in situ bacteria ( $<2 \mu \mathrm{m}$ fraction).

In May, the significantly higher degradation rate in the $<20 \mu \mathrm{m}$ size fraction corresponded to the unique presence of the large, heterotrophic, dinoflagellate Gyrodinium spirale. The absence of nauplii and other zooplankton organisms (Fig. 5G) indicated that G. spirale had an important impact on pellet degradation rate.

Fecal pellet degradation rate was significantly higher in the $<100 \mu \mathrm{m}$ size fraction as compared to the $<20 \mu \mathrm{m}$ fraction in all months (except September). Additionally, the pellet degradation rates in the fractions $<100$ and $<200 \mu \mathrm{m}$ were not significantly different in any month (Fig. 5). Thus, microplankton organisms in the size range of 20 to $100 \mu \mathrm{m}$ had a major impact on the degradation rate of fecal pellets in all months (except September) (Fig. 6). In September, the microplankton presumably had no impact $\left(r_{20-100 \mu \mathrm{m}}=0\right)$, but since we do not know the size of the bacterial contribution to the degradation rate we cannot say whether this was caused by a high bacterial degradation rate or by a high contribution from organisms in the $<20 \mu \mathrm{m}$ fraction (size range 2 to $20 \mu \mathrm{m}$ ). The possible microplankton candidates for causing the significant degradation rate in the specific size range of 20 to $100 \mu \mathrm{m}$ were large $(>20 \mu \mathrm{m})$ protozooplankton (dinoflagellates and ciliates) and nauplii, since copepods 

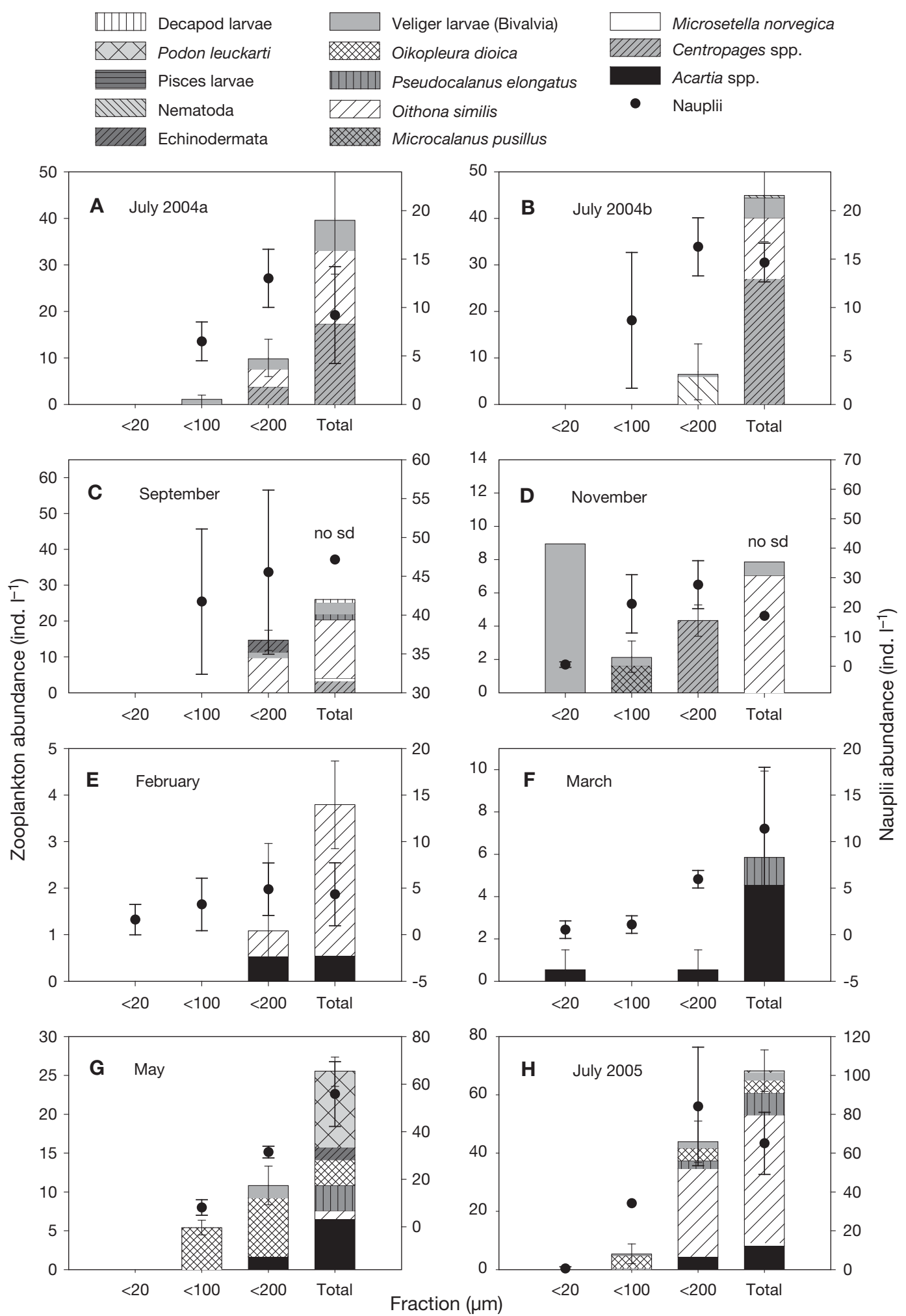

Fig. 4. Zooplankton. Abundance and species distribution of the dominating zooplankton groups and species in the 4 relevant fractions of each degradation experiment (mean of triplicate incubations) during different sampling months (A to H). No mesozooplankton organisms were found in the fractions $<0.2$ or $<2 \mu \mathrm{m}$. Naupliar abundance is represented separately by dots. The 2 degradation experiments in July 2004 were conducted with the same plankton community and fecal pellets, but the fragmentation percent $F$ (see Eq. 1) was 44 and $34 \%$ in July 2004 Expt a and b, respectively. The 'total' fraction represents the complete plankton community present in the unfractionated water samples. Note different scaling and different $y$-axes of nauplii and zooplankton 


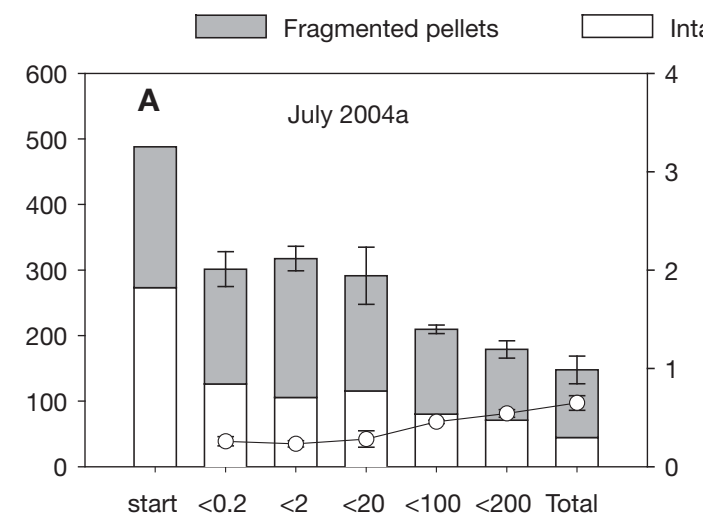

Intact pellets $\quad-0$ - Degradation rate $(r)$
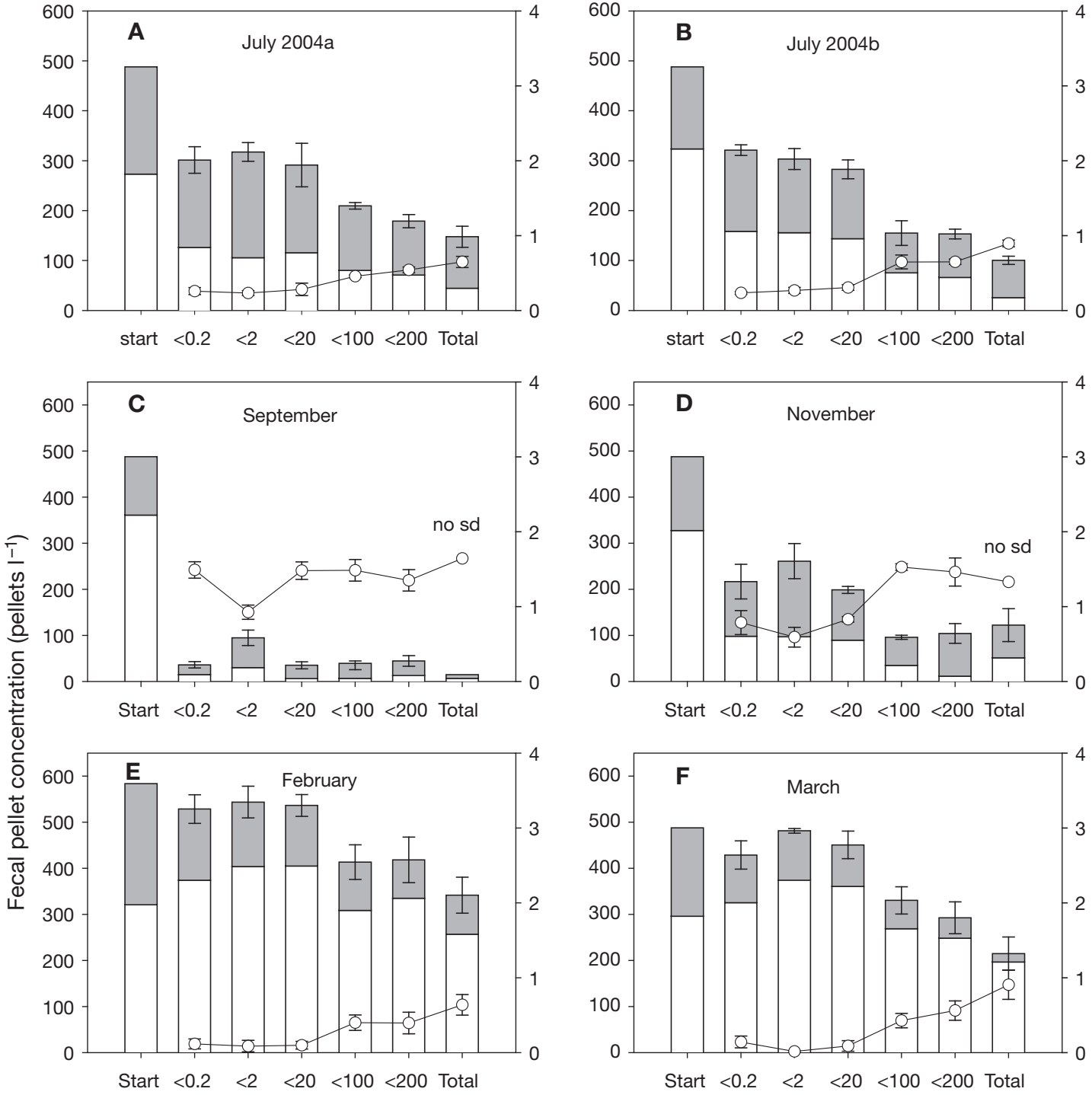

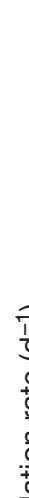
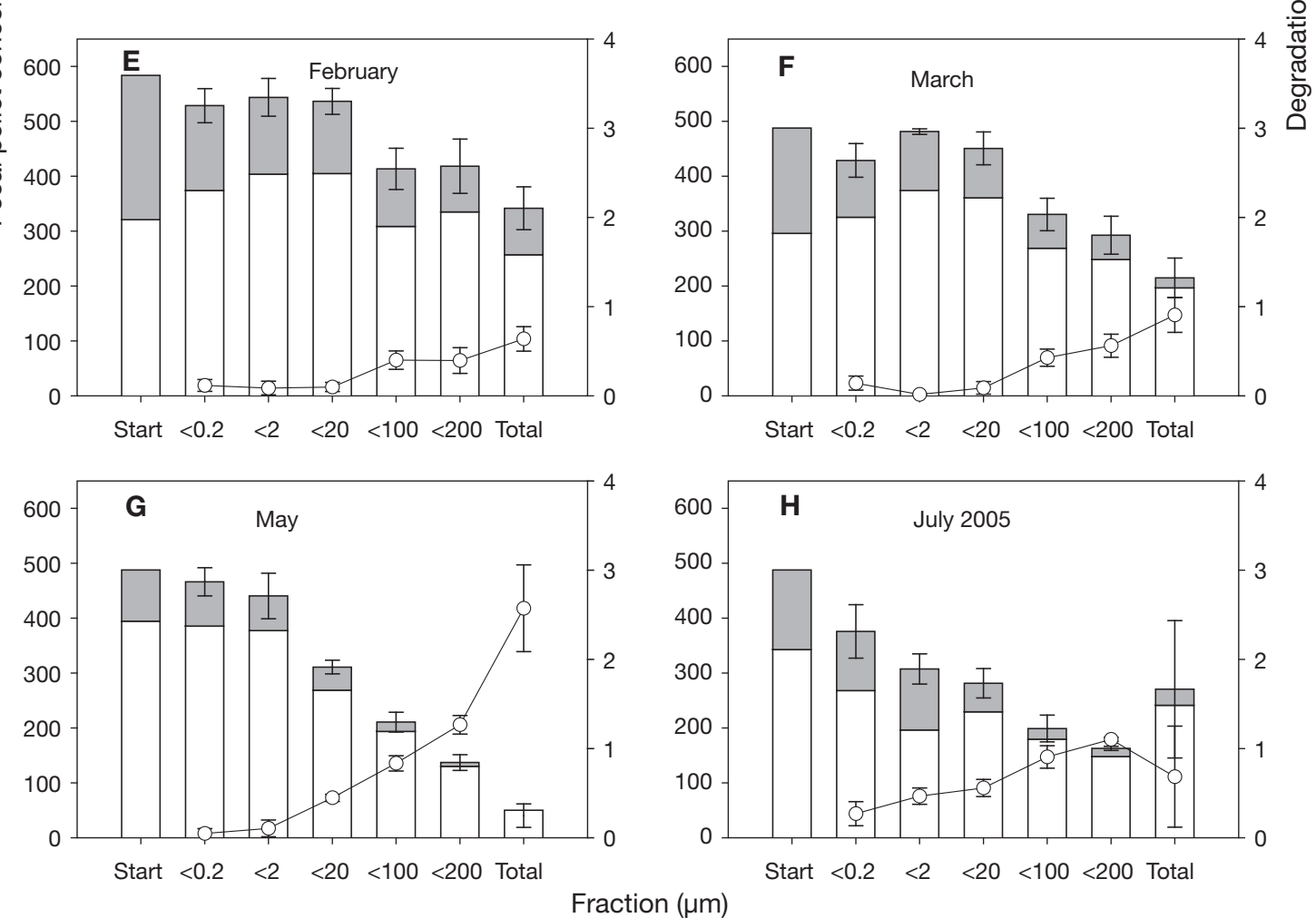

Fig. 5. Fecal pellets. Initial fecal pellet concentration, pellet concentration in each fraction and in the unfractionated plankton

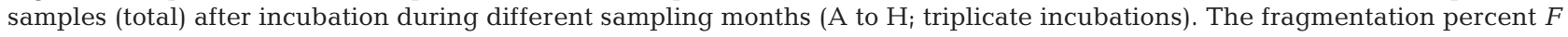
(see Eq. 1) is the grey area of the columns and the white area represents the percentage of intact pellets. The degradation rate estimated in each fraction is represented separately by dots. The 2 degradation experiments in July 2004 were conducted with the same plankton community and fecal pellets, but the fragmentation percentage $F$ (see Eq. 1) was 44 and $34 \%$ in July 2004 Expt $a$ and b, respectively. Note different $y$-axes 


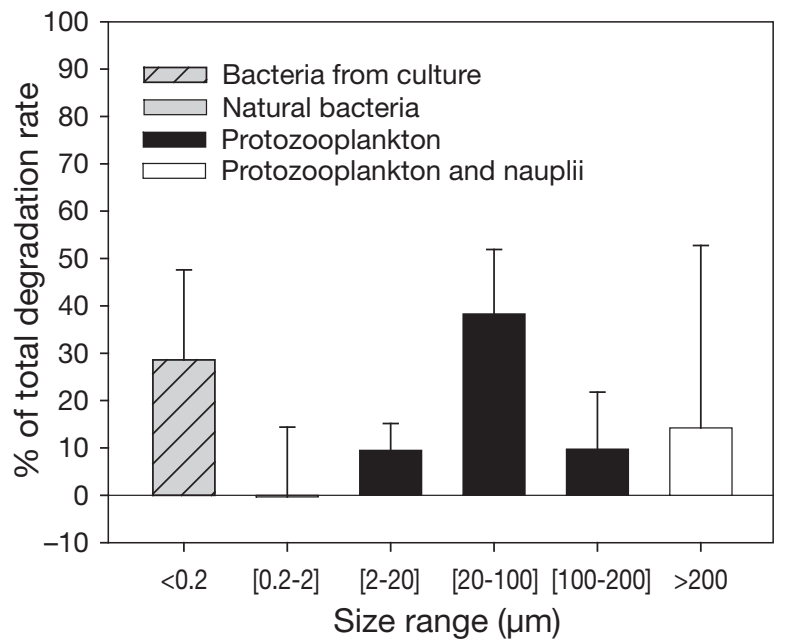

Fig. 6. Total degradation rate contributed by the different size ranges. The total degradation rate is split into the different size ranges and each size range is represented as the average $( \pm \mathrm{SD})$ of each month. September was not included in the calculation of the percent degradation due to the contamination of the $<0.2$ and $<2 \mu \mathrm{m}$ fractions. The degradation rate in the size ranges was calculated by subtracting the fractions from each other (e.g. $r_{20-100 \mu \mathrm{m}}=r_{<100 \mu \mathrm{m}}-r_{<20 \mu \mathrm{m}}$ ). The plankton organisms dominating the degradation in each size fraction are indicated by different patterns. Natural bacteria dominated the degradation in the $<2 \mu \mathrm{m}$ size fraction (this is difficult to see due to the minuscule size of the bar)

and other zooplankton occurred in the $<200 \mu \mathrm{m}$ to total fractions (Fig. 4). The microplankton in the size range of 20 to $100 \mu \mathrm{m}$ contributed from 15 to $53 \%$ of the total degradation rate $\left(r_{20-100 \mu \mathrm{m}}=0.18\right.$ to $\left.0.70 \mathrm{~d}^{-1}\right)$, excluding September. Linear regression showed that only the abundance of Gyrodinium spirale could be used as a predictor for the degradation rate in the 20 to $100 \mu \mathrm{m}$ size range $\left(\mathrm{r}^{2}=0.88, \mathrm{p}<0.01\right)$. However, $G$. spirale was not present in all months (present in November, March and May) and was not abundant (40 to 600 cells $\mathrm{l}^{-1}$ ). Other protozooplankton species $>20 \mu \mathrm{m}$ were, therefore, also important for the fecal pellet degradation rate, but could not be identified by the linear regression.

Copepods and other mesozooplankton were not important for the fecal pellet degradation rate in the present study, since the $<200 \mu \mathrm{m}$ and total fractions, containing the main part of the copepods and other zooplankton species, were not significantly different from the $<100 \mu \mathrm{m}$ fraction in most months (July 2004a, September, November, February, July 2005), including July 2004a and July 2005, when copepod abundance peaked (Figs. $4 \& 5$ ). The total degradation rate of the unfractionated plankton (total) was significantly different $(p<0.05)$ from the other fractions only in July 2004b, March and May. In these months mesozooplankton $(\geq 200 \mu \mathrm{m})$ contributed from 27 to $51 \%$ of the total degradation rate $\left(r_{(\geq 200 \mu \mathrm{m})}=0.25\right.$ to $\left.1.3 \mathrm{~d}^{-1}\right)$. Possible mesozooplankton candidates for causing the significant degradation rate in this size range were large protozooplankton, nauplii, copepods and other zooplankton organisms $\geq 200 \mu \mathrm{m}$. Linear regression showed that only the abundance of copepod nauplii could be used as a predictor for the degradation rate in the specific size range of $\geq 200 \mu \mathrm{m}$, including all months $\left(\mathrm{r}^{2}=0.98, \mathrm{p}<0.001\right)$.

The total degradation rate followed the phytoplankton biomass with a maximum in May $\left(2.57 \pm 0.49 \mathrm{~d}^{-1}\right)$ and a minimum in February $\left(0.64 \pm 0.14 \mathrm{~d}^{-1}\right)$, corresponding to a pellet removal rate of, on average, 42 to $95 \% \mathrm{~d}^{-1}$ (Fig. 2). However, this rate included the degradation rate provided by the $<0.2 \mu \mathrm{m}$ size fraction, which was caused by factors other than the natural plankton community of Øresund. Correcting for this contribution $\left(r_{(\text {total }}{ }^{*}\right)=r_{\text {(total) }}-r_{(<0.2 \mu \mathrm{m}) \text {, excluding Sep- }}$ tember), the corrected total degradation rate of the natural plankton community of Øresund ranged from 0.52 to $2.53 \mathrm{~d}^{-1}$ (Fig. 2), corresponding to a pellet removal rate of 22 to $87 \% \mathrm{~d}^{-1}$.

The degree of pellet fragmentation did not influence the degradation rates of the parallel degradation experiments in July 2004 (Table 2, Fig. 5A,B), since no significant difference was found between the degradation rates of the different fractions in Expts a and $b$ ( $t$-test, $\mathrm{p}>0.05)$.

\section{DISCUSSION}

Contrary to the general belief that copepods are the major degraders of fecal pellets in the sea (see review by Turner 2002) recent studies have shown that their role is minor (Reigstad et al. 2005, Poulsen \& Kiørboe 2006, Iversen \& Poulsen 2007). The present study investigates the degradation rate of fecal pellets in a plankton community and reveals which plankton organisms actually degrade fecal pellets.

The total degradation rate (corrected) of fecal pellets by the natural plankton community of Øresund ranged from 0.42 to $2.53 \mathrm{~d}^{-1}$, corresponding to a pellet removal rate of 22 to $87 \% \mathrm{~d}^{-1}$, which is within the range found in other field studies (Viitasalo et al. 1999, Wexels Riser et al. 2002, Sampei et al. 2004, Poulsen \& Kiørboe 2006), but lower than the maximum pellet degradation rates (12 to $13 \mathrm{~d}^{-1}$ ) found in Kiørboe (2003). The total degradation rate in the present study generally followed the seasonal variation of the phytoplankton. Maximum pellet degradation rates during maximum phytoplankton concentrations have been found in other studies in temperate and polar regions (UrbanRich 2001, Dubischar \& Bathmann 2002, Sampei et al. 2004). 


\section{Bacteria}

Bacterial degradation rates could be separated into the degradation rate contributed by culture-originating bacteria $(<0.2 \mu \mathrm{m}$ size fraction) and by free-living bacteria from Øresund ( $<2 \mu \mathrm{m}$ size fraction). Bacteria do not pass through a $0.2 \mu \mathrm{m}$ filter, and the degradation rates observed in this size fraction, therefore, originate from possible mechanical stress and bacteria supplied to the incubation bottles in association with the Acartia tonsa fecal pellets. The pellet degradation rate of the $<0.2 \mu \mathrm{m}$ size fraction in May was nearly zero $\left(0.05 \pm 0.06 \mathrm{~d}^{-1}\right.$; Fig. 6), the method used for handling and incubation was the same for all months; hence, the impact of mechanical stress in general was insignificant. Supporting this handling of the pellets did not cause a significant increase in pellet degradation rate in a control experiment (see 'Materials and methods'). We therefore conclude that the fecal pellet degradation rate in the size fraction $<0.2 \mu \mathrm{m}$ was caused by culture-originating bacteria associated with the added pellets.

The degradation rates were not significantly different in the $<0.2,<2$ and $<20 \mu \mathrm{m}$ fractions (except May), indicating that the culture-originating bacteria associated with the fecal pellets were the main bacterial degraders, whereas the contribution of the free-living naturally occurring bacteria was small. The bacterial degradation rates supplied by the culture-originating bacteria in the present study was an important part of the total degradation rate in some months, but highly variable. It ranged from approximately 0 to $0.031 \mathrm{~h}^{-1}$, which is within the range found in laboratory studies for flagellate-based pellets (Hansen et al. 1996, Thor et al. 2003, Olsen et al. 2005, Ploug et al. 2008).

Some impact of free-living bacteria in late-bloom situations was indicated in July 2005, where the degradation rate of the free-living bacteria was within the range of bacterial degradation rates obtained in laboratory studies for flagellate-based pellets (Hansen et al. 1996, Thor et al. 2003, Olsen et al. 2005, Ploug et al. 2008).

The bacteria were not enumerated in this study, and we are therefore unable to say whether or not the culture-originating bacteria were mainly attached to the surface of the pellets (Honjo \& Roman 1978), or within the pellets (Gowing \& Silver 1983). Dense populations of bacteria seeded within copepod fecal pellets have been observed in several studies (Gowing \& Silver 1983, Jacobsen \& Azam 1984, Tang 2005). Bacteria seeded within in situ fecal pellets may also be important for fecal pellet degradation in situ, and we can therefore only conclude that free-living natural bacteria did not have a significant impact in the present study. Further investigation into the bacterial degradation of in situ fecal pellets is obviously needed.

\section{Protozooplankton and nauplii}

The major impact of microplankton organisms in the size range of 20 to $100 \mu \mathrm{m}$ corresponded to the presence of large protozooplankton and early-stage nauplii $(<100 \mu \mathrm{m})$. However, only the abundance of Gyrodinium spirale could be used as a predictor for the degradation rate in this size range (linear regression). The importance of the protozooplankton as opposed to that of the mesozooplankton was supported by the fact that both the total degradation rate and corrected total degradation rate followed the abundance of the protozooplankton, and not that of nauplii or copepods. Thus, large protozooplankton $(>20 \mu \mathrm{m})$ were the main degraders of fecal pellets in this study. Plankton organisms $<200 \mu \mathrm{m}$ were also the main degraders of fecal pellets in a field study in the North Sea in August 2002 (Poulsen \& Kiørboe 2006) and in June 2007 (Iversen unpubl. data ), and Kiørboe (2003) found even higher degradation rates $\left(0.3\right.$ to $\left.13 \mathrm{~d}^{-1}\right)$ of the heterotrophic dinoflagellates Noctiluca scintillans on fecal pellets. Microscopic observations of Gyrodinium dominans, G. spirale and Protoperidinium spp. feeding on fecal pellets additionally confirm the ability of dinoflagellates to feed on fecal pellets (L. K. Poulsen unpubl. data, P. J. Hansen pers. comm.). Pellet degradation by the mainly benthic ciliate Euplotes sp. was directly observed in the present study. Faster degradation of pellets due to contamination with Euplotes sp. was also found by Hansen et al. (1996); and Lampitt et al. (1990) mentioned microscopic observations on ciliates with fecal pellets that suggested that they could cause substantial physical damage to the pellet after the peritrophic membrane was removed.

Taking the prey size spectrums into account, it becomes clear that dinoflagellates, and not ciliates, were most likely the main degraders in this study. Ciliates generally feed on prey $<20 \mu \mathrm{m}$, corresponding to an optimum prey size of 1/10 of their own size (Hansen 1992, Jakobsen \& Hansen 1997). Large ciliates were present in all months except July 2004 and November and were generally between 21 and $52 \mu \mathrm{m}$ in length, making them likely degraders only of small pellet fragments. The ciliates present in this study would therefore only be capable of degrading already fragmented pellets. However, large heterotrophic dinoflagellates are able to feed on particles many times larger than themselves with an optimum prey size of 1/1 (Hansen 1992, Jakobsen \& Hansen 1997). Large dinoflagellates are therefore able to consume intact fecal pellets, and their feeding strategy of attaching themselves to the food particle by a filament prior to consumption through direct engulfment, pallium feeding, or peduncle feeding (Hansen 1992) enables them to tow the fecal pellet, thereby counteracting the sinking rate of 
the pellet (L. K. Poulsen unpubl. data). Chemosensory capabilities and positive chemotaxis to food particles has been shown for heterotrophic dinoflagellates (reviewed by Verity 1991, Martel 2006). Likewise heterotrophic dinoflagellates detect fecal pellets by registering the chemical trail released by the pellet (L. K. Poulsen unpubl. data). Heterotrophic dinoflagellates are therefore easily able to detect, handle and consume copepod fecal pellets.

The optimum prey particle size for Gyrodinium spirale corresponds to its own size, and it is able to ingest prey that is 5.3 times its own volume with an efficiency as high as $75 \%$ (Hansen 1992). Average pellet volume was 1.2 to 4.1 times the average volume of $G$. spirale in the relevant months, and, thus, within the optimum size for $G$. spirale. The average fecal pellet clearance rate of $G$. spirale was approximately $1 \mathrm{ml}$ ind. ${ }^{-1} \mathrm{~d}^{-1}$, as estimated from 2 separate sources. Linear regression in the microplankton size range showed that the degradation rate increased at a rate of $0.0012 \mathrm{~d}^{-1}$ for every increase by 1 ind. $1^{-1}$, corresponding to a clearance rate $\left(F_{\text {G.spirale }}\right)$ of $1.2 \mathrm{ml}$ ind. ${ }^{-1} \mathrm{~d}^{-1}$. A similar clearance rate was obtained from the $<20 \mu \mathrm{m}$ fraction in May by assuming that $G$. spirale was the main degrader $\left(r_{2-20 \mu \mathrm{m}}=0.34 \mathrm{~d}^{-1}, G\right.$. spirale $\left.=0.36 \mathrm{cells} \mathrm{ml}^{-1}\right)$, yielding a clearance of $0.95 \mathrm{ml} \mathrm{cell}^{-1} \mathrm{~d}^{-1}$ equal to a pellet volume removal of 4 times the volume of an average $G$. spirale cell per day. These estimates are realistic since G. spirale clear similar-sized algae ( $\sim 50 \mu \mathrm{m}$ equivalent spherical diameter) at a rate of approximately $3 \mathrm{ml}$ ind. ${ }^{-1} \mathrm{~d}^{-1}$ (Hansen 1992). Using the average clearance rate of $1 \mathrm{ml}$ ind. $^{-1} \mathrm{~d}^{-1}, G$. spirale contributed from 7 to $52 \%$ of the corrected, cumulative degradation rate in the $<100,<200 \mu \mathrm{m}$ and total fractions. Hence, G. spirale had a large impact on the degradation rate, but could not alone explain the degradation rate in these fractions. Other large dinoflagellates therefore also contributed.

The pellet degradation rate was dependent on copepod nauplii abundance in the total fraction $\left(r_{\geq 200 \mu \mathrm{m}}\right)$, but not in the $<100$ or $<200 \mu \mathrm{m}$ fractions. This suggests that late stages of nauplii $>200 \mu \mathrm{m}$ contributed significantly to pellet degradation. However, the organisms of the $>200 \mu \mathrm{m}$ size range only contributed significantly to the total degradation rate in 3 months, whereas late-stage nauplii were present in all months, indicating a species-specific impact of nauplii. Naupliar consumption of fecal pellets is supported by 2 other studies (Green et al. 1992, Koski et al. 2005).

\section{Mesozooplankton}

Copepods (adults and copepodite stages) and other mesozooplankton did not influence the degradation rate significantly in the present study, since none of the copepod species, individually or together, could be used as predictors of the degradation rate of fecal pellets. This contradicts the former paradigm stating that copepods are the main degraders of fecal pellets (see review by Turner 2002). This paradigm was understandably based on the fact that adults of several copepod species have been found to clear fecal pellets in laboratory studies (Turner 2002). Likewise, Oithona similis females had clearance rates of $29 \mathrm{ml}$ ind..$^{-1} \mathrm{~d}^{-1}$ in a grazing experiment conducted in parallel with the degradation experiment in November (see Iversen \& Poulsen 2007). The cause of this seeming discrepancy between the high impact in laboratory grazing experiments and the low impact of copepods in natural plankton communities is that the laboratory studies have been conducted only with C5 or adult copepods, whereas natural copepod communities consist of a mix of stages. The copepod clearance rate of fecal pellets is size dependent, and the clearance rate of a given pellet size increases with increasing size of the copepod grazer (Poulsen \& Kiørboe 2005). Thus, the clearance rates of fecal pellets by in situ copepod communities consisting of a mix of copepodite stages and adults will always be much lower than those obtained for adult copepods only in the laboratory, as supported by the insignificant impact of copepods on pellet degradation rate found in recent studies (Reigstad et al. 2005, Poulsen \& Kiørboe 2006, Iversen \& Poulsen 2007). Behavioral studies of Acartia tonsa, Calanus helgolandicus and Pseudocalanus elongatus have shown that even the adult female copepods avoid or reject fecal pellets when possible, and that ingestion by suspension feeders appears to consist mainly of small fragments, which are ingested unintentionally along with food particles contained within the feeding current (Poulsen \& Kiørboe 2005, Iversen \& Poulsen 2007).

The direct impact of copepods on pellet degradation under natural conditions is therefore insignificant. However, copepods may be important for pellet degradation rate indirectly, since they exert a high grazing pressure on the main pellet degraders, such as the protozooplankton. This was illustrated in July 2005 when peak copepod abundances coincided with low abundances of large protozooplankton, and a corresponding decrease in the fecal pellet degradation rate in incubations with the total (unfractionated) plankton community.

\section{CONCLUSION}

Large protozooplankton (ciliates and dinoflagellates), and likely mainly heterotrophic dinoflagellates, were the main degraders of fecal pellets in this study. 
Free-living bacteria present in the natural seawater from Øresund did not have a significant impact on pellet degradation rate; however, culture-originating bacteria had a variable, but in some months important impact on the degradation rate of fecal pellets. Mesozooplankton in general did not have a significant impact on pellet degradation; however, an indirect impact was apparent through their grazing on the pellet degraders.

To our knowledge, this is the first study to demonstrate a general importance of protozooplankton for fecal pellet degradation. Hence, the effective 'coprophagous filter' responsible for the removal of fecal pellets within the water column (González \& Smetacek 1994) is more likely a 'protozoan filter'. The present study demonstrates that further investigation is required to identify the protozooplankton and nauplii species that degrade fecal pellets. Also, further investigation into the processes governing their impact is needed to fully understand and predict fecal pellet degradation and vertical material flux in the oceans.

Acknowledgements. We thank Prof. Thomas Kiørboe for comments and support during the experimental phase and for correcting the language of the manuscript. We also thank Dr. habil. Uta Passow from the Alfred-Wegener-Institute, and Dr. Ellen Jackson from Texas University for statistical help. L.K.P. was supported by the Carlsberg Foundation (2007_01_ 0495); and by the SLIP research school under the Danish Network for Fisheries and Aquaculture Research financed by the Danish Ministry for Food, Agriculture and Fisheries and the Danish Agricultural and Veterinary Research Council. M.H.I. was supported by the Danish Institute for Fisheries Research, Dept. of Marine Ecology and Aquaculture.

\section{LITERATURE CITED}

Ayukai T, Nishizawa S (1986) Defecation rate as a possible measure of ingestion rate of Calanus pacificus pacificus (Copepoda: Calanoida). Bull Plankton Soc Jpn 33(1):3-10

Dubischar CD, Bathmann UV (2002) The occurrence of faecal material in relation to different pelagic systems in the Southern Ocean and its importance for vertical flux. DeepSea Res II 49:3229-3242

González HE, Smetacek V (1994) The possible role of the cyclopoid copepod Oithona in retarding vertical flux of zooplankton faecal material. Mar Ecol Prog Ser 113: 233-246

González HE, González SR, Brummer GA (1994) Short-term sedimentation pattern of zooplankton, faeces and microplankton at a permanent station in the Bjørnafjorden (Norway) during April-May 1992. Mar Ecol Prog Ser 105: 31-45

Gowing MM, Silver MW (1983) Organisms and microenvironments of bacteria mediating fecal pellet decomposition in the sea. Mar Biol 73:7-16

Green EP, Harris RP, Duncan A (1992) The production and ingestion of faecal pellets by nauplii of marine calanoid copepods. J Plankton Res 14:1631-1643

Guillard RRL (1975) Culture of phytoplankton for feeding marine invertebrates. In: Smith WL, Chanley MH (eds)
Culture of marine invertebrate animals. Plenum Press, New York, p 29-60

Hansen PJ (1992) Prey size selection, feeding rates and growth dynamics of heterotrophic dinoflagellates with special emphasis on Gyrodinium spirale. Mar Biol 114: 327-334

Hansen PJ, Nielsen TG (1999) Dyreplankton i de danske farvande. Tema-rapport fra DMU, 28/1999, Miljø- og Energiministeriet, Copenhagen

Hansen B, Fotel FL, Jensen NJ, Madsen SD (1996) Bacteria associated with a marine planktonic copepod in culture. II. Degradation of fecal pellets produced on a diatom, a nanoflagellate or a dinoflagellate diet. J Plankton Res 18: 275-288

Honjo S, Roman MR (1978) Marine copepod fecal pellets: production, preservation and sedimentation. J Mar Res 36: 45-57

Iversen MH, Poulsen LK (2007) Coprorhexy, coprophagy, and coprochaly in the copepods Calanus helgolandicus, Pseudocalanus elongatus, and Oithona similis. Mar Ecol Prog Ser 350:79-89

Jacobsen TR, Azam F (1984) Role of bacteria in copepod fecal pellet decomposition: colonization, growth rates and mineralization. Bull Mar Sci 35:495-502

Jakobsen HH, Hansen PJ (1997) Prey size selection, grazing and growth response of the small heterotrophic dinoflagellates Gymnodinium sp. and the ciliate Balanion comatum-a comparative study. Mar Ecol Prog Ser 158: $75-86$

Kiørboe T (2003) High turnover rates of copepod fecal pellets due to Noctiluca scintillans grazing. Mar Ecol Prog Ser 258:181-188

Kiørboe T, Möhlenberg F, Riisgaard HU (1985) Bioenergetics of the planktonic copepod Acartia tonsa: relation between feeding, egg production and respiration, and composition of specific dynamic action. Mar Ecol Prog Ser 26: 85-97

Koski M, Kiørboe T, Takahashi K (2005) Benthic life in the pelagic: aggregate encounter and degradation rates by pelagic harpacticoid copepods. Limnol Oceanogr 50: 1254-1263

Lampitt RS, Noji TT, von Bodungen B (1990) What happens to zooplankton faecal pellets? Implications for material flux. Mar Biol 104:15-23

> Lintrup MJ, Jakobsen F (1999) The importance of Oresund and the Drogden Sill for Baltic inflow. J Mar Syst 18: 345-354

> Martel CM (2006) Prey location, recognition, and location by the phagotrophic marine dinoflagellate Oxyrrish marina. J Exp Mar Biol Ecol 335:210-220

Menden-Deuer S, Lessard EJ (2000) Carbon to volume relationship for dinoflagellates, diatoms, and other protist plankton. Limnol Oceanogr 45:569-579

Montagnes DJS, Lynn DH (1991) Taxonomy of choreotrichs, the major marine planktonic ciliates, with emphasis on the aloricate forms. Mar Microb Food Webs 5:59-74

Mullin MM, Sloan PR, Eppley RW (1966) Relationship between carbon content, cell volume, and area in phytoplankton. Limnol Oceanogr 11:307-311

Noji TT, Estep KW, MacIntyre F, Norrbin F (1991) Image analysis of faecal material grazed upon by three species of copepods: evidence for coprorhezy, coprophagy and coprochaly. J Mar Biol Assoc UK 71:465-480

> Olsen SN, Westh P, Hansen BW (2005) Real-time quantification of microbial degradation of copepod fecal pellets monitored by isothermal microcalorimetry. Aquat Microb Ecol 40:259-267 
Paffenhöfer GA, Knowles SC (1979) Ecological implications of fecal pellet size, production and consumption by copepods. J Mar Res 37:35-49

Paffenhöfer GA, Strickland JDH (1970) A note on the feeding of Calanus helgolandicus on detritus. Mar Biol 5:97-99

Paffenhöfer GA, Van Sant KB (1985) The feeding response of a marine planktonic copepod to quantity and quality of particles. Mar Ecol Prog Ser 27:55-65

Ploug H, Iversen MH, Koski M, Buitenhuis ET (2008) Production, oxygen respiration rates, and sinking velocity of copepod fecal pellets: direct measurements of ballasting by opal and calcite. Limnol Oceanogr 53:469-476

Poulsen LK, Kiørboe T (2005) Coprophagy and coprorhexy in the copepods Acartia tonsa and Temora longicornis: clearance rates and feeding behaviour. Mar Ecol Prog Ser 299:217-227

Poulsen LK, Kiørboe T (2006) Vertical flux and degradation rates of copepod fecal pellets in a zooplankton community dominated by small copepods. Mar Ecol Prog Ser 323: 195-204

Reigstad M, Wexels Riser C, Svensen C (2005) Fate of copepod faecal pellets and the role of Oithona spp. Mar Ecol Prog Ser 304:265-270

Sampei M, Sasaki H, Hattori H, Fukuchi M, Hargrave BT (2004) Fate of sinking particles, especially fecal pellets, within the epipelagic zone in the North Water (NOW) polynya of northern Baffin Bay. Mar Ecol Prog Ser 278: $17-25$

Støttrup JG, Richardson K, Kirkegaard E, Pihl NJ (1986) The cultivation of Acartia tonsa Dana for use as a live food source for marine fish larvae. Aquaculture 52:87-96

Editorial responsibility: Otto Kinne, Oldendorf/Luhe, Germany
Tang KW (2005) Copepods as microbial hotspots in the ocean: effects of host feeding activities on attached bacteria. Aquat Microb Ecol 38:31-40

Thomsen HA (ed) (1992) Plankton i de indre danske farvande. Miljøstyrelsen, Copenhagen

Thor P, Dam HG, Rogers DR (2003) Fate of organic carbon released from decomposing copepod fecal pellets in relation to bacterial production and ectoenzymatic activity. Aquat Microb Ecol 33:279-288

Tomas CR (ed) (1997) Identifying marine phytoplankton. Academic Press, San Diego, CA

- Turner JT (2002) Zooplankton fecal pellets, marine snow and sinking phytoplankton blooms. Aquat Microb Ecol 27: $57-102$

Urban-Rich J (2001) Seston effects on faecal pellet carbon concentrations from a mixed community of copepods in Balsfjord, Norway, and the Antartic Polar Front. ICES J Mar Sci 58:700-710

Utermöhl H (1958) Zur Vervollkommung der quantitativen Phytoplankton-Methodik. Mitt Int Ver Theor Angew Limnol 9:1-38

Verity PG (1991) Feeding in planktonic protozoans: evidence for non-random acquisition of prey. J Protozool 38:69-76

Viitasalo M, Rosenberg M, Heiskanen A, Koski M (1999) Sedimentation of copepod fecal material in the coastal northern Baltic Sea: where did all the pellets go? Limnol Oceanogr 44:1388-1399

> Wexels Riser C, Wassmann P, Olli K, Pasternak A, Arashkevich E (2002) Seasonal variation in production, retention and export of zooplankton faecal pellets in the marginal ice zone and central Barents Sea. J Mar Syst 38:175-188

Submitted: August 16, 2007; Accepted: June 16, 2008 Proofs received from author(s): August 19, 2008 